\title{
TERA FAEDAH DAN TERA ROHANI: NILAI PRAGMATIS SYAIR TERBITAN BALAI PUSTAKA SEBELUM PERANG
}

\author{
Zaenal Hakim \\ Badan Pengembangan dan Pembinaan Bahasa \\ Email: zaenalhakim45@yahoo.co.id \\ HP: 0877818554844
}

ABSTRACT

\begin{abstract}
This study revealed the terms of pragmatics in the poem Boedjanglong way off(1927), daughters of Boerdah Poems (1931), and Poems Koerban Boeroe (tt). As a work laden with ethical values-moral, the three poems that express mandate of each will bebeneficial for the human spirit. Ethics-mandated moral is: SBJ encourage mankind to be forgiven, SPB contains the suggestionthat humans do not do treason, and LCS suggested that applicable human patient. As a work of narrative, the poem presents all three conflicts caused by overly ambitious leaders in getting the treasure, throne, and women. As the substance of the story, the three elements have filled in beautifully for the flow calibration of each story.
\end{abstract}

Key words: theory of pragmatic, ethical values; tera avail; and tera lovely

\begin{abstract}
ABSTRAK
Penelitian ini mengungkapkan segi pragmatik dalam Syair Boedjang Djaoeh (1927), Syair Poeteri Boerdah (1931), danSyair Koerban Boeroe (t.t.). Sebagai karya yang sarat dengan nilai-nilai etika-moral, ketiga syair tersebut masing-masing mengungkapkan amanat yang akan berfaedah bagi rohani manusia. Etika-moral yang diamanatkan yaitu: SBJ menganjurkan manusia supaya bersikap memaafkan, SPB berisi anjuran supaya manusia tidak berbuat berkhianat, dan SKB menganjurkan supaya manusia berlaku sabar. Sebagai karya narasi, ketiga syair tersebut menyuguhkan konflik disebabkan para tokoh terlalu ambisius dalam mendapatkan harta, tahta, dan wanita. Sebagai substansi cerita, ketiga unsur tersebut sudah mengisi tera indah bagi alur masing-masing kisah.
\end{abstract}

Kata kunci: teori pragmatik; nilai etika; tera faedah; dan tera indah

\section{PENDAHULUAN \\ Latar Belakang}

Syair merupakan salah satu bentuk sastra dalam khazanah kesusastraan Melayu yang pada masanya cukup banyak digemari sebagai media untuk berekpresi pada penulisnya. Warisan sastra Melayu yang lain di antaranya hikayat, pantun, dan "cheretera" (prosa). Sebelum ditemukan mesin cetak, penerbitan syair dilakukan secara manual tulis tangan. Aksara yang digunakannya disebut huruf Jawi, yaitu sistem penulisan yang memanfaatkan huruf Arab (dengan sedikit modifikasi) untuk menuliskan syair berbahasa Melayu. Balai Pustaka yang berdiri mulai tahun 1917 dan sebagai penerbit yang menandai era modern, menjadi bagian yang ikut menghidupkan kesusastraan syair ini.

Hingga masa sebelum PD II, syair benyak ditulis orang dalam majalah- majalah. Bahkan penerbit Balai Pustaka hingga masa setelah Kemerdekaan banyak menerbitkan syair dalam bentuk buku-buku, antara lain, Syair Poetri Hijaoe (anonim, 1924) Syair Si Boedjang Djaoeh (Kadiroen, 1927, selanjutnya disingkat SBDJ), Syair Poeteri Boerdah(A. Rahman, 1931, selanjutnya disingkat SPB), dan Syair Kurban Buru (Dt. Bandaro Kajo, t.t. selanjutnya disingkat SKB). Pada masa sekarang karya sastra berbentuk syair sangat sulit ditemukan di Indonesia. Oleh karena itu, penelitian ketiga syair ini menjadi kesempatan yang sangat berharga. Saya tidak menyertakan Syair Putri Hijau, sebab cetakan awal (1924) syair ini belum ditemukan. Sebaliknya, Syair Kurban Buru, sekalipun tanpa mencantumkan angka tahun penerbitan, diikutsertakan sebagai sampel penelitian karena tipografi cetakan bukunya menunjukkan hasil-hasil cetakan awal Balai Pustaka sebelum Kemerdekaan. 
Liaw Yock Fang dalam bukunya Sejarah Kesusastraan Melayu(1978: 12) mengatakan bahwa menurut isinya syair Melayu terbagi atas enam golongan, yaitu (1) syair panji, (2) syair romantis, (3) syair kiasan, (4) syair sejarah, (5) syair agama, dan (6) syair nasihat. Berdasarkan pembagian ini, maka isi ketiga syair yang diteliti bisa dimasukkan ke dalam syair romantis. Aspek romantis dalam (Syair Kurban Buru) terletak dalam penggambaran penghidupan masyarakat desa pada masa dahulu ketika kondisi alam masih utuh.

Penelitian syair yang pernah dilakukan Pusat Pembinaan dan Pengembangan Bahasa rata-rata sebagai hasil studi filologis terhadap naskah berhuruf Jawi. Masing-masing, yaitu "Analisis Struktur dan Nilai Budaya dalam Syair Sultan Mahmud di Lingga, Syair Banjarmasin, dan Syair Raja Siak" oleh Sunardjo (1995), "Analisis Struktur dan Nilai Budaya dalam Syair Kuripan” oleh Fanani (1996), "Analisis Struktur dalam Syair Ismar Yatim" oleh Jaruki (1997), "Syair Siti Zuhrah: Suntingan Teks dan Analisis Struktur" dan "Analisis Struktur dan Nilai Budaya Sja'ir Poeteri Hidjau dan Sja'ir Sitti Aminah" keduanya oleh Yundiafi (1997). Satu penelitian hasil ditujukan terhadap naskah-naskah syair yang sudah tercetak buku, dimaksudkan untuk penulisan skripsi pada Fakaultas Sastra UI, yaitu "Dari Jalanan Kereta Api Sampai Kembang, Satu Studi Atas Syair-Syair Tan Teng Kie" oleh Edwina Satmoko Tanojo (1993).

\section{Masalah}

Penelitian ini hendak menjawab masalah- masalah manfaat atau aspek pragmatis karya sastra ragam syair pada masa sebelum Kemerdekaan, sebagai berikut.

1) Aspek-aspek pragmatis (manfaat) yang bagaimanakah yang terdapat dalam syair yang diteliti.

2) Bagaimana cara aspek- aspek manfaat tersebut hadir dalam syair.

Masalah pertama berkaitan dengan aspek tema dan masalah yang kedua berkaitan dengan aspek estetis suatu karya sastra.

\section{METODE PENELITIAN}

Penelitian ini menggunakan metode analisis deskriptif. Dalam metode analisis deskriptif semua data yang dianalisis dan hasil- hasil temuan yang hendak dicapai (aspek pragmatis) dideskripsikan sebagai satu komposisi wacana ilmiah. Alasan pemilihan sampel jatuh pada SKB, SPB, dan SBDJ adalah (1) naskah sudah dipublikasikan oleh Balai Pustaka sebagai penerbit yang mapan pada zamannya, (2) naskah belum pernah diteliti oleh siapapun, dan (3) nilai-nilai pragmatis yang ada (nilai faedah dan nilai rohani) dalam ketiga karya tersebut menjadi aspek penting bagi pendidikan.

Tujuan penelitian ini yaitu hendak mengetahui nilai-nilai manfaat sebagai aspek pragmatis karya sastra. Manfaat karya sastra, antara lain, terletak dalam ajaran moral yang menjadi obsesi para penulisnya. Fungsi bentuk sebagai alat untuk menyampaikan obsesi tersebut, tetap menyertai pembicaraan mengenai aspek pragmatik dalam ketiga syair tersebut. Karena bagaimanapun, sastra sering dilihat sebagai suatu bentuk filsafat, atau sebagai pemikiran yang terbungkus dalam bentuk khusus (Wellek \& Austin Warren, 1989: 134). Kadang-kadang hal ini dikemukakan secara eksplisit, namun ada kalanya tersembunyi di dalam salah satu unsur struktur, yaitu tema (Zaimar, 2014: 27).

\section{ESTETIKA SYAIR}

Sekalipun syair masuk dalam hasil karya klasik kesusastraan Melayu, sebagai karya individu dalam syair ditemukan pembaharuan-pembaharuan. Pembaharuan ini bisa sebagai bentuk pelarian dari bentuk kaku peraturan, bisa pula sebagai kreativitas murni pengarang. 
Tetapi untuk melihat proses atau perkembangan pembaharuan kita harus bertumpu pada bentuk konvensi yang diperbaharui tersebut. Konvensi yang belum berubah dalam ketiga syair yang diteliti yaitu alur maju sebagai alur tradisional dan amanat yang menganjurkan segala kebaikan sebagai norma yang diakui bersama. Sementara pembaruan yang dilakukan, sangat kentara, terdapat dalam "kebebasan" menetukan jumlah kata dalam larik syair.

Alur maju dalam SKB diisi oleh pergulatan saling memusnahkan di antara manusia lawan babi. Dalam konflik tersebut babi berada di pihak yang menang. Kekalahan yang ditanggung manusia mencakup moril maupun materil. Namun faktor emosianal lebih mendramatisir kekalahan tersebut. Tumbangnya satu per satu anggota keluarga Pendekar Gantang sebagai kurban keganasan babi, lebih menyedihkan daripada ancaman hilangnya hasil palawija oleh babi sebagai unsur penggerak cerita. Sebagai korban, manusia tidak berdaya mengatasi musuhnya itu. Di akhir cerita sang ibu dari keluarga yang diharu biru babi itu (Ibu Rajudin) harus meninggal dunia karena tak kuat menanggung beban psikis tersebut. Alur SKB merupakan alur maju.

Unsur penggerak atau akar masalah yang menjiwai alur maju SPB adalah faktor kecantikan pada tokoh utama. Kecantikan Putri Gamariah membuat dirinya menjadi rebutan para dewa di kayangan dan di dunia juga. Alur SPB merupakan alur maju yang mengandung dua tujuan dari dua tokoh dari dunia yang berbeda (kayangan dan dunia), maka dalam SPB terjadi "buka tutup" distribusi penceritaan secara bergantian.

Dalam SBJ ambisi kekuasaan merupakan permasalahan yang mengisi alur maju sebagai penggerak cerita. Ambisi tersebut secara tegas terkandung dalam hati tokoh antagonis bernama Sultan Hangat. Dengan penggambaran wataknya yang "hitam" ia melakukan tindakan murtad dengan membunuh orang tuanya angkatnya demi memperoleh kekuasaan. Sesuai wataknya yang kasar dan ambisius, namanya pun kemudian diberi julukan "Hangat Garang”. Akan tetapi, norma kepantasan tidak mengizinkan tokoh garang ini mencapai maksudnya itu.

Konvensi lain yang tak berubah dalam syair-syair yang diteliti yaitu sudat pandang. Dapat dikatakan, sudut pandang merupakan instrumen yang menghubungkan cerita, penutur, dan pengarangnya dalam sebuah narasi. Pembaruan dalam aspek ini sudah menunjukkan celah-celah yang bisa dikembangkan pada masa yang akan datang.

Ditinjau dari aspek penceritaan, penutur syair SKB adalah orang ketiga yang berada di luar cerita, yang oleh sebab itu ia tidak terlibat dalam permasalahan/konflik cerita. Ketika penutur tampil ke muka menyapa pembaca, berbagai istilah yang jadi sinonim "cerita" muncul, sepertikissah, warta, kabar, madah, cerita, kalam, sahibulhikayat, dan peri. Bentuk-bentuk sapaan penutur menjadi semacam kendali betapa kita mengikuti seluruh kisah melalui mulut penutur. Sudut pandang sebagai aspek yang menunjukkan posisi pengarang saat bertutur, sangat jelas terasa dari aspek pemakaian bahasa. Misalnya, dengan sangat nyata penutur membawa pembaca pada posisi cerita akan dimulai, cerita memasuki masalah pokok, mengawali adegan baru, mengakhiri adegan, ataupun mengakhiri kisah secara seseluruhan.

Penutur SPB sadar betul akan posisinya sebagai pencerita. Dengan sikap merendah ia mengakui (atau merendah?) bahwa dirinya bukan sebagai pengarang pertama, melainkan hanya menceritakan cerita orang lain ("kata yang menceritakan"'hlm. 12 atau "orang punya rencana"/hlm. 63). Dalam tiap awal pergantian atau pun penutupan adegan, penutur selalu menyapa pembaca.. Kata-kata sapaan penutur biasanya muncul ketika kisah/adegan akan dimulai atau ketika akan diakhiri.

Dalam SBJ munculnya penutur menyapa pembaca ketika ia akan mengawali adegan mengakhiri cerita, atau ketika ia merasa perlu untuk segera menggarap bagian lain. Misalnya: Kisahnya tidak beta lanjutkan (hlm. 82), Beralih kissah kabar dan peri (hlm. 83), Kabarnya tidak Mandeh panjangkan (hlm. 121), dan lain-lain. Dua kali tercatat penutur 
berusaha melibatkan emosionalnya ke dalam cerita, yaitu ketika ia mengomentari kisahnya sendiri: "Kita tentu ma'lum sendiri" (hlm. 90) dan ketika ia menambahkan: Itulah kabar cerita orang/Supaya anakku mendapat terang (hlm. 141). Sebenarnya keterlibatan emosional semacam itu lazim terjadi dalam karya sastra lisan/"dilisankan" yang melibatkanaudiens sebagai pihak ketiga. Dengan demikian, aspek ini termasuk pembaharuan dalam SBJ.

\section{Bahasa Gaya}

Gaya bahasa memperlihatkan gabungan kakofoni (kemerduan bunyi vokal) dengan konsonan, misalnya: Dipagar dengan bilah dan buluh/skb dan Wahai saudara sedaun semakan dan simetri rima sekaligus simetri makna ke dalam pola gurindam dua larik, misalnya: Dari dunia sudah tenggelam/Tidakkan dapat lagi diselam dan Hatinya tidak menjadi sejuk/Kusut sebagai segumpal ijuk(hlm. 57). Formula gurindam ini ditemui juga dala naskah SPB, seperti: Pekan lenyap, bulan menjelma/Purnama berganti tahun bernama (hlm. 120).

Beberapa ungkapan gaya (style) yang memanfaatkan dua larik syair yang terdekat serta yang mendekatkan rima sekaligus makna, menjadikan pola ini merupakan kebulatan makna dan kebulatan sintaktik, terdapat pula dalam SBJ sebagai berikut.

Kepalanya putus bunyi berdesir/Bagai memarang pisang sesisir (hlm. 14)

Ia selalu bermuram durja/Sebagai bulan gerhana senja (hlm. 44)

Karena ia orang penyantun/Tidak membedakan sutra dan katun (hlm. 100)

Terdapat ungkapan yang muncul utuh dalam puisi modern Ajip Rosidi: Sepasang mata biji saga (Teeuw, 1979: 42, 53)

Panas hatinya tidak terhingga/Matanya merah umpama saga (hlm. 124).

Dalam SKB sering ditemui klausa terbalik, di mana posisi inti yang harus berada di depan (hukum DM) malah ada di belakang (MD). Dalam hubungan sebuah kalimat yang sempurna kesalahan ini jelas sangat mengganggu dan bisa salah arti. Contoh: Berburu adat dilakukan tentu, seharusnya: Adat berburu dilakukan tentu. Ungkapan-ungkapan khas bahasa Melayu-Minang: "menduai" 'menandingi' (hlm. 33)skb; "orang bersifat" 'orang bijak' (hlm. 30), dan "pemagar negeri" 'keamanan kampung' yang sebenarnya bisa diadopsi menjadi ungkapan bahasa Indonesia modern.

Kesan pertama mengamati bahasa SPB adalah munculnya kosa kata-kosa kata yang berasal dari bahasa Arab yang belum diserap ejaannya ke dalam bahasa Melayu/Indonesia. Istilah-istilah tersebut selalu diikuti pleh predikat yang berasal dari bahasa Arab yang sifatnya inklusif (hanya dimengerti kalangan yang menyelami ajarannya), seperti musta'id '...' (hlm. 17,124), Allah subhana (hlm. 25), "Astaga firu'llah" (hlm. 32), "Tuhan yang baka" (hlm. 33), "waziru” ' 'lam" (hlm. 33, 61); "Tuhan subhana"(hlm. 39),putri yang sahda/hlm. 79), dan "iradat" (hlm. 127) dalam SPB.

Terdapat gejala pemendekan kata dalam SKB yang sifatnya individual, yaitu untuk bentukanmenanti cukup ditulis dengan manti saja. Ekonomi bahasa dalam naskah SPB terdapat pada kata surisebagai pemendekan dari permaisur, misalanya: Suripun setuju akan niatan (hlm. 28) dan kata ama 'hama' yang kini menjadi "hama": Meskipun kecil sebesar ama (hlm. ...).

Pluktuasi pemaknaan terdapat pada kata gonggong yang berkolokasi pada binatang serangga kumbang: Segera digonggong kumbang yang sakti (hlm. 73). perbedaan kolokasi juga terdapat pada kata cinta, pada syair mengandung makna sebagai 'gelisah' atau 'duka': Selama Burdah lenyap dimata/Suami isteri sangat bercinta.//Santap dan beradu tiada bertentu (hlm. 113).

\section{Larik Asimetri}

Empat larik masing-masing berjumlah empat kata dengan anggota kata-kata tunggal, menjadi dasar penulisan sebait syair. Akan tetapi, pengarang tidak mungkin membuat semua larik dengan empat kata tunggal. Terdapat perpaduan kelas kata, jabatan kata, jenis kata 
sambung (dan, yang, dan oleh) dan kata tugas, yang tidak sekelas dengan kata tunggal. Akibatnya, timbul ketegangan dalam sebuah larik syair taat aturan (simetris), sehingga produksi larik berkualitas dalam syair menjadi demikian relatif. Masalah ini malahirkan larik asimetri, yaitu larik-larik yang disisipi kata-kata nontunggal dan kata-kata yang tidak sekelas dengan kata tunggal.

Larik-larik terdiri atas empat kata tetapi disisipi kata sambung:

Contoh dalam SKB:

Lepas kita dari jambatan

Menunggui si sakit berganti-ganti

Tingginya konon kalau dikira

Bukan tunggul sebagai dikata

Contoh dalam SPB:

Gawatamala dan Kesna ratu

Maharaja Kesna dan permaisuri

Putri Burdah dan permaisuri

Beroleh putri yang bijaksana

Demikianlah kata yang menceritakan

Diiringkan oleh rakyat tentara

Dalam SBJ pengarang berusaha untuk taat azas pada estetika simetri syair "empat kata dalamsatu larik". Tetapi pengarang tidak menganggap kata sambung (dan, yang, dan nan) sebagai bagian dari kata yang berdiri sejajar dengan kata-kata tunggal, sehingga secara jumlah kata-kata dalam larik menjadi lima.

Contoh:

Rahman dan rahim ada segala

Allah dan rasul dipuji sudah

Salah dan khilaf maaf dipinta

Pleh ulama yang pasih lidah.

Itulah pemberian dagang yang papa

Yang lain itu haram semata

Dalam bahasa Minangkabau kata nan berarti 'yang'. Tetapi dalam SBJ penggunaan kata nanyang tidak semata sebagai pengganti yang, seolah menjadi satu formula ungkapan syair, padahal kehadirannya bisa dihilangkan.

Contoh-contoh:

Teman nan jangan dijadikan seteru (hlm. 26)

Dukar nan suka tidak terkira (hlm. 29)

Malang nan tidak dapat ditolak (hlm. 31)

Hangat nan sudah dapat kemenangan (hlm. 32)

Baginda nan suka tidak terperi (hlm. 35, 42)

Hangat nan sangat bersuka cita (hlm. 44)

Mandeh nan lalu ia dapati (hlm. 110)

Dalam SBJ ditemui keunikan berupa penulisan kata dengan angka:

Laksana purnama 14 hari (h. 58)

Dua kata ulang dalam satu larik:

Tangkap-menangkap serang-menyerang" (104)

Dua kata yang dalam satu larik:

Ada yang tertutup ada yang tersingkap (hlm. 53) 
Hadirnya kata tunggal yang hanya satu suku kata (misalnya: hal, tak, dan lain-lain.), kata majemuk (misalnya: balaiirung, berdukacita, malapetaka, dll.), kata ulang (misalnya: Makan-makanan, Berbagai-bagai, Gilang-gemilang, dll.), kata sambung (misalnya: ke, dan, dari, kepada, oleh, yang, dll.), kata tugas (misalnya: bagai), dan kata sandang (misalnya: si), mendatangkan masalah bagi kegenapan sebuah syair. Masalah dalam estetika syair muncul ketika hadir sebuah larik berjumlah 3 kata, 5, dan 6 kata.

Contoh larik berjumlah 3 kata dalam SKB:

Besar kira sepemagutan

Sepenebangan kayu cemara

Dipohonkan pada Chalikurbahri

Kotatengah nama Negara

Berbagai-bagai pula namanya

Contoh larik berjumlah $3 \mathrm{kata} \mathrm{dlm}$. SPB:

Gawatamala sultan bernama

Setiap hari bercengkrama

Baginda bersama permaisuri

Menduduki singgasana dibalaiirungsari

Makan-makanan juga diisi

Contoh larik berjumlah $\mathbf{3}$ kata dalam SBJ:

Contoh dalam satu bait:

Setiba dirumah sekaliannya

Lalu berbunyi bunyi-bunyiaannya

Serta segala permainannya

Girang menyambut kedatangannya

(hlm. 105)

Contoh larik berjumlah 5 kata dalam SKB:

Air mata mengalir sepenuh pipi

Lima belas tahun lebih tiada

Lepas Gantang empat belas hari

Kesedihan mereka $t a$ ' dapat ditahan

Anak dan suami tak terlupakan/skb

Meski tak punya ibu dan anak/skb

$T a$ ' dapat dibayar atau diganti/skb

Babi tak mungkin lari keseberang

Dosa si mati Allah ampunkan

Contoh Larik berjumlah 5 Kata dlm SPB:

Air mata cucur, pipinya basah

Ta' pernah kelihatan bersenang hati

Kami datang dari Santa barbara

Mendapatkan Kesna raja yang sakti

Rakyat berhimpun tanjung dan selat

Sampailah konon ke Santia Vesna-

Mengunjungi Kesna di Santa Barbara

Ingin bertemu si jantung hati 
Contoh larik berjumlah 5 kata dalam SBJ:

Serta ku 'amalkan setiap waktu

Lalu bermimpi duli syah 'alam

Hati rasa cemas ta' sabar

Contoh larik berjumlah 6 kata dalam SKB:

Hilalang 'kan tumbuh tak mungkin jadi

Lurah dan sawah, rimba dan hutan

Si mati terhindar dosa yang keji

Mujur ta' hilang 'akal si Janang

\section{Istilah dan Konsep Modern}

Konsep modern di tengah masyarakat agraris muncul dalam penggunaan istilah musyawarat (hlm. 40), bersidang (hlm. 40), dan jabatan (hlm. 41) dalam SKB, sebagai istilah dalam dunia organisasi. Penggunaan kata Minggu sebagai nama hari terasa demikian "tegar" mengingat sudah ada istilah Ahadyang berasal dari bahasa Arab.

Dalam SKB terdapat penggunaan bahasa yang menunjukkan semangat modern dalam wawasan pengarang. Kata-kata yang dimaksud yaitu rapat, pesawat, kapal udara, dan Minggu. Kata rapat(berapat/hlm. 19)) digunakan di samping "musyawarat" yang berasal dari bahasa Arab. Demikian pula kata pesawat digunakan dalam pengertian menunjuk pada salah satu jenis kendaraan modern yang berjalan di udara. Hanya anehnya, padanan untuk "pesawat" pun ternyata sama-sama digunakan, yaitu "kapal udara". Konsep modern di tengah masyarakat agraris muncul dalam penggunaan istilah musyawarat (hlm. 40), bersidang (hlm. 40), dan jabatan (hlm. 41) yang muncul.sebagai istilah dalam dunia organisasi. Penggunaan kata Minggu sebagai nama hari terasa demikian "tegar" mengingat sudah ada istilah Ahadyang berasal dari bahasa Arab.

Bahasa Melayu sebagai sumber bahasa Indonesia modern, terlihat jejak-jejaknya dalam SBJ. Misalnya, kata ajung yang kita gunakan dalam bentuk singkatan "ATM" (ajung tunai mandiri) ditemukan dalam syair ini. Kata lainnya antara lain: jeda 'rehat/istirahat' (Diparang ayahku tiada berjeda/hlm. 14);alpa 'lupa/lalai' (Ayahku heran menjadi alpa/hlm. 14). Istilah sepak bola masa kini, sumbernya dari sepak raga dalam bahasa Melayu. Dalam larik: Disepaknya sekalian sebagai raga (hlm. 66), tersedia istilah sepak raga yang dimodifikasi ke dalam kalimat kreatif. Istilah petualang (petualang/ petualangan) berasal dari tualang, dalam syair ini "hantu tualang" (hlm. 100). Kata mutu sinonim 'kualitas' semula mempunyai arti "manik-manik": Diatas tahta bertatahkan mutu (hlm. 79); bisa berarti pula 'hal yang positif' seperti senang/girang; berhati mutu $><$ berhati walang, bisa juga bentuk sifat mutu 'elok, indah' dijadikan kata bilangan: Puteri ma'arajat emas semutu (hlm. 187).

Pemakaian bahasa Melayu yang kemudian muncul dalam pemakaian di zaman modern kini menarik untuk dicermati. Imbuhan -da/nda seperti dalam Inangda $(\mathrm{hlm}$. 98), ibunda, anakanda; ayahanda, kakanda; adinda (hlm. 38) sebagai bentuk posesif, yang menunculkan kata sapaan "anda". Peringkasan kata reta sebagai bentuk singkat dari 'kereta' (hlm....); suri dari 'permaisuri' (hlm. 37, 38, 58).

Kata nobat yang melahirkan istilah penobatan, rupanya semula berkaitan erat dengan upacara di kerajaan. Untuk menarik perhatian khalayak supaya mereka bisa mendengarkan pengumaman dari raja, Dipalulah nobat serunai nafiri (hlm. 16). Misalnya dalam pengumuman tentang kelahiran anak raja sebagai berikut. Jadi, penobatan bukan berasal dari kata dasar tobat. Sumbangan lain terdapat ungkapan "pencakar langit" untuk menyebut sebuah bangunan istana yang menjulang tinggi (hlm. 71). Kosa kata sila sebagai bahasa santun, sangat boleh jadi lahir dalam lingkungan keluarga istana, Disilakan Kesna bersama suri (hlm. 48). 
Ditemukan pemakaian gaya bahasa yang memanfaatkan pola gurindam (larik dua baris), seperti: Pekan lenyap, bulan menjelma/Purnama berganti tahun bernama (hlm. 120). Ekonomisasi bahasa terdapat pada gejala pemendekan kata dalam SKB yang sifatnya individual, yaitu untuk bentukan menanticukup ditulis dengan manti saja; dalam SPB kata suri sebagai pemendekan dari permaisuri dalam: Suripun setuju akan niatan (hlm. 28), dan kata ama 'hama' yang diambil dari "hama": Meskipun kecil sebesar ama. Dalam SKB sering ditemui klausa terbalik, di mana posisi inti yang harus berada di depan (hukum DM) malah ada di belakang. Dalam tingkat klausa suatu perubahan konstruksi bisa menimbulkan salah arti. Contoh dalam SKB: Berburu adatdilakukan tentu; seharusnya: Adat berburu dilakukan tentu.

Sebagai sebuah wacana sastra lama yang terkategori istana sentris, dalam hal pemberian nama-nama tempat, naskah SPB menunjukkan satu keunikan. Terutama nama-nama kerajaan sebagai ikon pertama bagi pembaca, nama-nama itu memberi kesan sebagai nama-nama yang berasal dari kawasan Eropa, seperti nama negeri Santia Vesna dan negeri Santa Barbara.

\section{Tera Indah: Harta, Tahta, dan Wanita}

Harta, tahta, dan wanita sampai kini masih menjadi adagium bagi para pemimpin yang terlalu berlebihan untuk mendapatkan ketiganya. Keserakahan untuk memperoleh ketiganya akan menimbulkan konflik-konflik di antara manusia itu sendiri. Demikian pula dalam ketiga syair yang diteliti, konflik yang terbentuk muncul disebabkan para tokoh terlalu ambisius dalam mendapatkan ketiga "kebutuhan" tersebut. Akan tetapi, sebagai substansi cerita, ketiga unsur tersebut bisa dikatakan mengisi tera indah bagi alur masing-masing kisah. Unsur harta, tahta, dan wanita sebagai bahan konflik di antara para tokoh, terjalin dalam satu kisah narasi, menjadi daya tarik tersendiri, sehingga ketiga unsur itu masuk dalam azas keindahan dalam karya sastra.

Unsur harta dalam SKB berbeda modus dengan harta yang terdapat dalam kisah SKB.Dalam SKB harta benda rakyat menjadi hal yang harus dipertahankan dari ancaman serangan binatang babi. Disebabkan babi sudah menjadi penyebab jatuhnya korban manusia, maka dilakukanlah perburuan babi secara besar-besaran, “... dibuat mufakat/Segala orang berhimpun serikat/Babi diburui senjata diangkat" (hlm. 10). Jadi, berlainan dengan konvensi syair lama yang istana sentris, SKB sudah menyajikan peristiwa kontekstual sehari-hari seperti itu.

Kondisi babi sebagai binatang liar yang digambarkan mempunyai kekuatan yang sangat besar menjadi satu-satunya tokoh antagonis dalam cerita ini. Hal demikian menimbulkan konflik yang terus memanas dan memakan korban jiwa manusia sampai akhir cerita.

Tahta sebagai tujuan akhir ambisi kekuasaan, menjadi satu-satunya unsur penggerak dalam cerita SBDJ. Ambisi tersebut secara tegas terkandung dalam hati tokoh antagonis Sultan Hangat Garang. Dengan pelukisan wataknya yang digambarkan sangat "hitam" ia melakukan tindakan murtad membunuh orang tua angkatnya sendiri demi memperoleh kekuasaan.

Hangat Garang berhasil merebut tahta Raja Tua, tetapi permaisuri berikut kandungan putra mahkota berhasil diselamatkan oleh raja jin ke hutan bambu. Putra mahkota yang dibesarkan di hutan bersama para binatang, setelah dewasa menjadi anak angkat Mandeh Rubiah dan diberi nama Bujang Jauh. Lewat didikan Mandeh Rubiahlah Bujang Jauh diperkenalkan cara-cara hidup dalam masyarakat manusia.

Sebelum berhadapan dengan Hangat Garang, Bujang Jauh berhasil menolong kerajaan kecil Sidoak Doai (dan mendapat hadiah wanita (mempersunting) Putri Ma'arajat) dari kekejaman Raja Gumantah.

Bujang Jauh diberi tahu raja jin tentang pengkhianatan Hangat Garang terhadap ayah kandungnya dengan cara menghukum gantung ayahnya dan mengasingkan ibunya ke hutan 
bambu. Dalam melakukan perhitungan keadilan dengan Hangat Garang dan ia keluar sebagai pemenang dalam pertempuran melawan Hangat Garang. Dengan bantuan raja Jin mayat ayah dan ibu Bujang Jauh dapat dihidupkan kembali.

Unsur wanita sebagai hal yang menjadi sumber keserakahan manusia, ditemukan dalam SPB. Unsur penggerak atau akar masalah yang menjiwai perjalanan cerita SPB adalah kecantikan Putri Gamariah sejak menghuni surgaloka. Kecantikannya selalu menjadi rebutan para dewa. Hal ini menimbulkan bentrokan di antara para dewa yang saling bersaing mendapatkan Putri, sehingga kayangan menjadi kacau. Keadaan itu membuat Batara Indera sebagai penguasa kayangan jadi murka.

Dewa mengasingkan Putri Gamariah ke dunia dengan membungkus sang Putri ke dalam "sarung hikmat". Di dunia Putri Gamariah kelak menitis pada bayi permaisuri Raja Kesna. Kelahiran Bayi titisan Putri Gamariah yang diberi nama Putri Burdah merupakan ganjaran bagi Raja Kesna yang banyak beribadat dan ia mendambakan turunan. Tetapi akibat masih terbungkus dengan sarung hikmat, kulit sang bayi menjadi berwarna hitam. Baru di usianya yang ke-16 Putri Burdah berubah menjadi cantik.

Sebagai warga dunia pun Putri Burdah menjadi penyulut permusuhan antara Solida dengan Hangat Garang, dua satria yang menyintainya. Dewa Forta yang masih memburu Putri Gamariah di dunia, berhasil menculik Putri Burdah ke kahyangan. Tetapi Solida dengan dibantu gurunya (Berahmana Hamman), dan dengan mengubah diri menjadi seekor kumbang, mampu memboyong kembali putri kecintaannya ke dunia.

Cerita berakhir bahagia bagi pihak Solida karena raja muda ini di samping telah berhasil mempersunting Putri Burdah, ia pun menjadi pewaris Kerajaan Santa Vesna dan dapat berkumpul kembali kedua orang tuanya.

\section{Tera Faedah: Berakhlak Baik}

Di balik kasus harta, tahta, dan wanita yang melatari timbulnya konflik dalam alur masing-masing syair di atas, diperoleh ajaran moral atau etika lewat aspek amanat supaya manusia berakhlak baik. Amanat dalam masing-masing kisah yaitu, dalam kisah SKB berupa anjuran supaya manusia berlaku sabar, dalam SPB berupa anjuran supaya manusia tidak berbuat berkhianat, dan dalam SBDJ berupa anjuran supaya manusia supaya manusia bersikap memaafkan.

Amanat dalam SKB bahwa manusia harus memiliki kesabaran dalam menghadapi musibah timbul karena para tokoh mengalami musibah berupa keganasan hama babi dan kegagalan dalam menangani masalahnya. Kegamangan manusia dalam menyikapi makhluk babi membuat mereka dan kehilangan kepercayaan diri.

\section{Informasi Budaya}

Membaca SKB kita dibawa pada satu permasalahan di salah satu kampung di Sumatera bagian Barat, yang bergulat untuk melawan atau memusnahkan hama babi. Dalam pergulatan tersebutlah kita memperoleh pengetahuan tentang satu tradisi masyarakat yang dibentuk justru karena adanya masalah itu, sifatnya khas karena lahir dari tuntutan di tempat yang bersangkutan, yaitu kebiasaan berburu babi.

Berburu bagi masyarakat Suliki berburu merupakan satu profesi. Dengan berburu pemburu bisa mempunyai penghasilan, walau finansial yang ia peroleh disebabkan oleh rasa terima kasih masyarakat karena hama yang menjadi momok sudah musnah. Imbalan jasa tersebut bisa berupa bahan-bahan makanan hasil pertanian seperti ubi dan talas (Ubi dan talas dikirimnya/Sebagai balas jerih payahnya/hlm. 44) juga padi (Lain dari itu diberi padi/Setiap tahun seberapa sudi/hlm. 41). Dari rakyat yang merasa telah menerima jasanya, Pendekar Janang memperoleh berbagai hak istimewa lagi, seperti doa (keselamatannya) dari seluruh warga. 
Tupai dipohon binatang bajingan

Merugikan negeri bukan bandingan

Merusakkan buahan berkepanjangan

Ditembaki Pendekar banyak bilangan.

Adapun jasa Pendekar berani

Tiada dilupakan oleh pa' tani

Selalu disebut disana-sini

Serta didoakan pada Rabbani.

(hlm. 44)

Lewat permusyawaratan desa akhirnya Rajudin dinobatkan sebagai tetua buru, menggantikan jabatan ayahnya yang menjadi korban keganasan babi. Sebagai Tua Buru ia diberi gelar "Pendekar Muda". Rajudin bersama Pendekar Janang masing-masing diberi bedil pemburu oleh Datuk Kepala. Bedil adalah senjata yang hanya dimiliki oleh seorang hulubalang. Dengan bedil itu keduanya bukan hanya membasmi babi dan hama tanaman lainnya (bajing), tetapi keamanan negeri dari bahaya kriminal pun mereka jaga. Demikian besar peran keamanan ini sampai-sampai seluruh penduduk ikhlas memberi hasil tanaman dan mendoakan terhadap semua kebaikan dalam kehidupannya.

Dengan perannya yang amat penting bagi para warga desa, keberadaan para pemburu seperti sudah dilembagakan serta mempunyai aturan-aturan sendiri. Misalnya, jumlah mereka sebagai tim inti ada delapan orang, sehingga namanya muncul dalam istilah "dubalang delapan". Warga yang tidak bisa menunaikan kewajibannya dalam meronda, harus didenda. Dan hasil dendanya digunakan untuk keperluan para pemburu atau keamanan desa juga. Mereka mendapat sumbangan "alat kelengkapan/Untuk pakaian" (hlm. 10)skb dari hasil denda warga yang tak bisa meronda.

Sebagai bagian dari perangkat desa, penjabat pimpinan pemburu diberi nama khas, yaitu "Tua Buru" (hlm. 13)skb yang kadang disebut "Pendekar panglima" atau "Pendekar bahari" (hlm. 22)skb. Bisa jadi kepupolerannya melebihi kepala kampung sendiri (pemimpin kaum; kepala kampung; lurah) yang diberi nama "Datuk Kepala" (hlm. 17)skb, atau "Datuk Penghulu" (hlm. 21)skb, dan juga "Datuk utama" (hlm. 21)skb. Mengingat perannya yang demikian penting, masalah yang menimpa sektor keamanan menjadi penting dibicarakan dalam satu rapat pertemuan yang oleh pengarang disebut dengan istilahmusyawarat (hlm. 40) atau bersidang (hlm. 40).

Lepas Gantang empat belas hari

Musyawarat orang dalam negeri

Duduk bersidang dibalairung sari

Ganti si Gantang hendak dicari.

(hlm. 49)

Ketua pemburu pun mendapat hak-hak istimewa, antara lain ia dibebaskan dari kewajiban kerja rodi (Tua-buru lepas berodi) dan mendapat jaminan pemberian beras sesukanya (Lain dari itu diberi padi/Setiap tahun seberapa sudi/hlm. 41). Perlakuan istimewa yang diperoleh ketua pemburu yang paling berharga yaitu ketika ia mendapat sebuah senapan yang akan digunakan dalam bertugas. Sekalipun hadiah itu bersifat pribadi, yaitu pemberian Datuk Kepala sendiri sebagai lurah desa.

Selain sistem informasi tentang pranata sosial budaya setempat, pertama-tama tradisi peribadatan agama Islam mendapat penggarapan yang khusus dari pengarang SKB. Bukan sekadar mencerminkan tradisi keberagamaan Islam saja, tetapi sudah terdapat kritik atas ajaran yang sedang dijalankan. Dalam sejarah perkembangan Islam, kritik agama ini timbul dalam rangka gerakan pemurnian Islam di Pulau Sumatra, terutama Sumatra Barat. Sesuai dengan 
konteks cerita, kebiasaan menyelenggarakan ritual dalam peristiwa kematian mendapat perhatian yang krusial dalam naskah SKB. Ritual tahlilan dalam kutipan berikut mencerminkan suatu tradisi masyarakat saat salah satu anggota keluarga meninggaldunia.

Kemudian berkata Datuk utama:

Wahai kita 'alim 'ulama

Datanglah kerumah Pendekar panglima

Mengaji tahlil bersama-sama

Jika boleh pinta diberi

Sekalian 'ulama dalam negeri

Mengaji sampai ketujuh hari

Untuk arwah Pendekar bahari.

(hlm. 22)

Sebaliknya, bagi keluarga yang mendapat musibah kematian tidak diwajibkan memasak dengan maksud untuk menyediakam tamu yang melayat. Peristiwa ini menjadi bagian penekanan terhadap maksud memurnian ajaran Islam dalam naskah SKB.

Orang mengaji tak minum makan

Ahli dilarang menyediakan

Karena begitu sudah dilazimkan

Aturan agama orang lakukan.

(hlm. 27)

Sementara tradisi tahlinan untuk sebagian besar penganut agama Islam di Indonesia masih dianggap sebagai bagian dari syariat agama Islam. Tradisi membacakan doa-doa dan zikir (Selain dari orang mengaji/ tahlil dibaca 'ulama dan hajihlm. 28), masih diyakini sebagai bagian dari ritual kematian. Tahlilan dianggap mampu membantu meringankan perjalanan arwah ke alam baqa.

Kritik itu pun ditunjukkam pada aspek kebiasan masyarakat meratapi mayat dengan berlebih-lebihan seperti dalan naskah SKB, Bandunglah ratap segala ahli/Biarpun dilarang 'ulama dan wali/Tetapi mereka tidak peduli (hlm. 24), serta kebiasaan mengantar jenazah ke pemakaman dari kaum perempuan. Sebenarnya terdapat larangan bagi kaum perempuan baik dari kalangan keluarga maupun orang lain untuk ikut mengantarkan mayat ke kuburan.

... famili ta' kelihatan

Dilarang mengikut gadis pingitan

Karena takut diharu setan

Nanti mereka lupa ingatan

(hlm. 26)

Sekalipun demikian, syariat agama dijalankan dengan kritis. Misalnya, terdapat kritik berupa larangan makan atau minum apapun di rumah orang tempat yang mendapat musibah kematian, makanan kita tegahkan.

Supaya kita jangan menyusahkan

Menyedia makanan kita tegahkan

Sekadar tahlil dihadiahkan

Minta arwahnya Allah lapangkan.

(hlm. 22)

Menyumbangkan harta untuk kesejahteraan sarana peribadatan termasuk ajaran dalam agama Islam. Dalam naskah SKB hal ini menjadi aspek paling akhir sebagai syiar Islam yang ingin ditonjolkan. Disebabkan dalam keluarga Pendekar Muda tak lagi ada ahli waris lagi setelah kematian sang ibu, akhirnya dengan mempercayakan pengelolaannya kepada kadi, 
warga sepakat untuk mewakafkan seluruh harta hasil penjualan benda-benda milik janda itu untuk dipergunakan bagi kemaslahatan masjid.

...

Berpulang semua anak dan bunda

Waris yang dekat tiada ada.

Mufakat segala penghulu bestari

Harta ibu pendekar jauhari

Dijual semua meja almari

Uang disimpan Kadi negeri.

Harta wakaf sudahlah tentu

Pembaiki mesjid berlantai batu

Pembantu anak yatim piatu

Kadi mengurus satu persatu.

(hlm. 60)

\section{SIMPULAN}

Dalam suatu karya yang baik terkandung nilai-nilai estetik dan etik sekaligus. Kedua aspek itu merupakan persenyawaan dalam satu karya seni apapun. Nilai etik menjadi isi kandungan atau representasi pikiran/ideologi penciptanya, sementara aspek estetik merupakan bentuk pengungkapan kesenian yang dipilih penciptanya.

Dengan adanya nilai-nilai etika yang bisa dipetik dalam ketiga naskah syair, maka pendekatan yang paling sesuai dalam pembahasan ini adalah teori pragmatik. Penerapan teori pragmatik akan melihat aspek kegunaan dari sebuah karya sastra. Teori Abram selengkapnya terdiri atas aspek mimetik, pragmatik, ekspresif, dan objektif. Pendekatan pragmatik Abram sejalan dengan teori Braginsky yang memandang karya sastra memiliki tiga tera/lapis faedah sebagaimana ditranfer oleh Abdul Hadi. Teori Braginsky lahir berdasarkan pengamatan terhadap sastra Melayu genre syair. Menurut Braginsky, keindahan dalam sastra Melayu asli memiliki tiga tera makna, yaitu (a) tera indah, (b) tera faedah, dan (c) tera rohani.

Harta, tahta, dan wanita sebagai bahan konflik di antara para tokoh, terjalin dalam satu kisah narasi, menjadi daya tarik tersendiri, sehingga ketiga unsur itu masuk dalam azas keindahan dalam karya sastra. Dalam ketiga syair yang diteliti, konflik yang terbentuk muncul disebabkan para tokoh terlalu ambisius dalam mendapatkan ketiga "kebutuhan" tersebut. Akan tetapi, sebagai substansi cerita, ketiga unsur tersebut bisa dikatakan mengisi tera indah bagi alur masing-masing kisah.

Di balik dinamika kehidupan yang menyangkut harta, tahta, dan wanita, berdasarkan konflik dalam alur masing-masing syair di atas, diperoleh ajaran moral atau etika lewat aspek amanat supaya manusia berakhlak baik. Amanat dalam masing-masing kisah yaitu, dalam kisah SKB berupa anjuran supaya manusia berlaku sabar, dalam SPB berupa anjuran supaya manusia tidak berbuat berkhianat, dan dalam SBDJ berupa anjuran supaya manusia supaya manusia bersikap memaafkan.

Gaya bahasa dalam ketiga syair memperlihatkan kreativitas penggabungan kakofoni (kemerduan bunyi vokal) dengan konsonan yang menyatukan kebulatan makna dan kebulatan sintaktik. Misalnya:Dipagar dengan bilah dan buluh (SKB); Pekan lenyap, bulan menjelma/Purnama berganti tahun bernama (SPB); dan Kepalanya putus bunyi berdesir/Bagai memarang pisang sesisir (SBJ).

Dalam kondisi pengarang yang tidak mungkin membuat semua larik dengan empat kata tunggal, syair harus mengakomodasi kata-kata dalam kelas dan jabatannya, kata sambung (dan, yang, dan oleh), dan kata tugas, yang tidak sekelas dengan kata tunggal. Akibatnya, timbul 
ketegangan dalam sebuah larik syair taat aturan (simetris), sehingga produksi larik berkualitas dalam syair menjadi demikian relatif. Masalah ini malahirkan larik asimetri, yaitu larik-larik yang disisipi kata-kata nontunggal dan kata-kata yang tidak sekelas dengan kata tunggal.

Bahasa Melayu sebagai sumber bahasa Indonesia modern, terlihat jejak-jejaknya dalam ketiga syair. Kata ajung yang kita gunakan dalam bentuk singkatan "ATM" (ajung tunai mandiri) ditemukan dalam syair SBJ. Kata lainnya antara lain: jeda 'rehat/istirahat' (Diparang ayahku tiada berjeda/hlm. 14);alpa 'lupa/lalai' (Ayahku heran menjadi alpa/hlm. 14). Istilah sepak bola masa kini, sumbernya darisepak raga dalam bahasa Melayu. Dalam larik: Disepaknya sekalian sebagai raga (hlm. 66), tersedia istilah sepak raga yang dimodifikasi ke dalam kalimat kreatif. Istilah petualang (petualang/ petualangan) berasal dari tualang, dalam syair ini "hantu tualang" (hlm. 100). Pemakaian bahasa Melayu yang kemudian muncul dalam pemakaian di zaman modern kini menarik untuk dicermati. Imbuhan $\mathrm{da} / \mathrm{nda} \quad$ seperti dalam Inangda (hlm. 98), ibunda, anakanda; ayahanda, kakanda; adinda (hlm. 38) sebagai bentuk posesif, yang menunculkan kata sapaan "anda". Kata nobat yang membentuk istilah penobatan, semula berkaitan erat dengan upacara di kerajaan dalam budaya Melayu. Untuk menarik perhatian khalayak supaya mereka bisa mendengarkan pengumaman dari raja, Dipalulah nobat serunai nafiri. Ungkapan "pencakar langit" untuk menyebut sebuah bangunan istana yang menjulang tinggi, semula berasal dalam naskah SBJ. 


\section{DAFTAR PUSTAKA}

Liaw Yock Fang. 1975. Sejarah Kesusastraan Melayu Klasik. Singapura: Pustaka Nasional.

Wellek \& Austin Warren. 1989. Teori Kesusastraan. Terjemahan dari Thery of Literature (1977) leh Melani Bunanta. Jakarta: Gramedia.

Zaimar, Okke K.S.. 2014. Pengantar Teori Kesusastraan. Jakarta: Gramedia.

Hadi W.M., Abdul. 2002. t.t. "Estetika dan Seni sebagai Ungkapan Religiusitas" (naskah belum diterbitkan).

Yudiono K.S. 1986. Pengantar Teori Kritik Sastra. Bandung: Angkasa. 